\title{
Restriction endonuclease analysis of Aspergillus fumigatus DNA
}

\author{
J P Burnie, A Coke, R C Matthews
}

\begin{abstract}
Aims: To develop a genome based DNA fingerprinting system for Aspergillus fumigatus mould.

Methods: DNA was extracted from 21 isolates obtained from eight patients with an aspergilloma. This was with a freezedried mycelial extract fragmented in liquid nitrogen. DNA was subsequently purified by phenol-chloroform extraction followed by ultracentrifugation on a caesium chloride gradient. The DNA was restricted by EcoRI and Xba I.

Results: All isolates were identical when cut by EcoRI; Xba I delineated six DNA types.

Conclusions: DNA fingerprinting can be used to type isolates of $A$ fumigatus. Strains from within an aspergilloma which were morphologically distinct could either have the identical DNA fingerprint or produce a unique type.
\end{abstract}

Aspergillus fumigatus has recently been described as a cause of nosocomial infection producing clusters of invasive disease that was associated with hospital building work. ${ }^{1-3}$ It is important to be able to differentiate isolates as outbreaks due to a single source such as an infected air filter can be distinguished from a cluster of cases due to an overall increase in the spore count.

Conventional techniques such as phage typing, antibiograms, and plasmid profiles are clearly inappropriate with fungal moulds. Immunoblot fingerprinting has been previously applied to $A$ fumigatus and this phenotype based system generated 11 types among the 21 isolates from eight patients with an aspergilloma. ${ }^{4}$ This technique was laborious and involved growing up each isolate and fragmenting it by mechanical pressure. The resulting supernatants were run on a $10 \%$ sodium dodecyl sulphate polyacrylamide gel electrophoresis (SDS-PAGE) gel and transblotted on to a nitrocellulose membrane. They were developed in a modified enzyme linked immunosorbent assay (ELISA) with a rabbit hyperimmune antiserum raised against $A$ fumigatus NCPF 2109.

In recent years there has been an upsurge of interest in genotype based restriction fragment length polymorphisms (RFLPs) of total cellular DNA as a means of typing microorganisms. This technique has been successfully applied to several human fungal pathogens including Candida albicans, ${ }^{56}$ Torulopsis glabrata, ${ }^{7}$ Candida parapsilosis, ${ }^{8}$ Candida tropicalis, ${ }^{9}$ Histoplasma capsulatum, ${ }^{10}$ Trichophython rubrum ${ }^{11}$ and Absidia glauca. ${ }^{12}$ Distinction between isolates depended on differences in either mitochondrial or ribosomal DNA. ${ }^{13}$ In the case of $C$ albicans 16 different genotypes were identified among 45 isolates from five outbreaks of systemic candidosis and 94 control isolates. This was with the restriction enzyme EcoR $I^{5}{ }^{5}$

\section{Methods}

Twenty one isolates from eight cases of aspergilloma were examined. They were identified as $A$ fumigatus by their standard cultural characteristics and microscopic appearance. $A$ fumigatus NCPF 2109 was the control isolate.

Each isolate was subcultured on to Sabouraud's dextrose agar and grown at $30^{\circ} \mathrm{C}$ for 48 hours. It was inoculated into Sabouraud's dextrose broth and grown for a period of three to five days at $30^{\circ} \mathrm{C}$ in an orbital shaker rotating at $3000 \mathrm{rpm}$. The mycelium was harvested by filtration and the solid culture was freeze-dried overnight at $4^{\circ} \mathrm{C}$. The freezedried mycelium was harvested in liquid nitrogen. To each gram of white suspension 10 $\mathrm{ml}$ of extraction buffer was added. Each $100 \mathrm{ml}$ contained $20 \mathrm{ml} 1 \mathrm{M}$ TRIS pH 8, $25 \mathrm{ml} 1 \mathrm{M}$ sodium chloride, $5 \mathrm{ml}$ of $0.5 \mathrm{M}$ EDTA, pH 8.5, $2.5 \mathrm{ml} 20 \%$ SDS and $47.5 \mathrm{ml}$ of sterile distilled water. This was mixed with a bulb pipette and stored on ice for 30-60 minutes. It was split in two aliquots of $5 \mathrm{ml}$. To each was added $3.5 \mathrm{ml}$ of phenol and $1.5 \mathrm{ml}$ chloroform:isoamyl alcohol. It was spun for one hour at $5000 \mathrm{rpm}$. This was repeated and $200 \mu \mathrm{l}$ of $20 \mathrm{mg} / \mathrm{ml}$ of RNase was added to each preparation. This was incubated in a water bath at $37^{\circ} \mathrm{C}$ for 30 minutes. The nucleic acid was phenol/ chloroform and chloroform extracted. It was precipitated overnight at $-20^{\circ} \mathrm{C}$ in ethanol. It was spun at $4^{\circ} \mathrm{C}$ for 20 minutes at $10000 \mathrm{rpm}$.

After centrifugation the precipitated nucleic acid was washed with $70 \%$ cold ethanol. The precipitate was dried and resuspended in $3 \mathrm{ml}$ TE of (10 mM TRIS-hydrochloride buffer, pH 7.5, 1 mM EDTA, pH 7.5).

To every $\mathrm{ml}$ of sample $1 \mathrm{~g}$ of $\mathrm{CsCl}$ was added. The volume was made up to $10 \mathrm{ml}$ in a Beckman tube. Ethidium bromide ( $300 \mu$ l of 10 $\mathrm{mg} / \mathrm{ml}$ ) was present in each tube. Samples were centrifuged at $48000 \mathrm{rpm}$ at $17^{\circ} \mathrm{C}$ for 70 hours. The DNA band was collected after centrifugation.

The ethidium bromide was removed by 


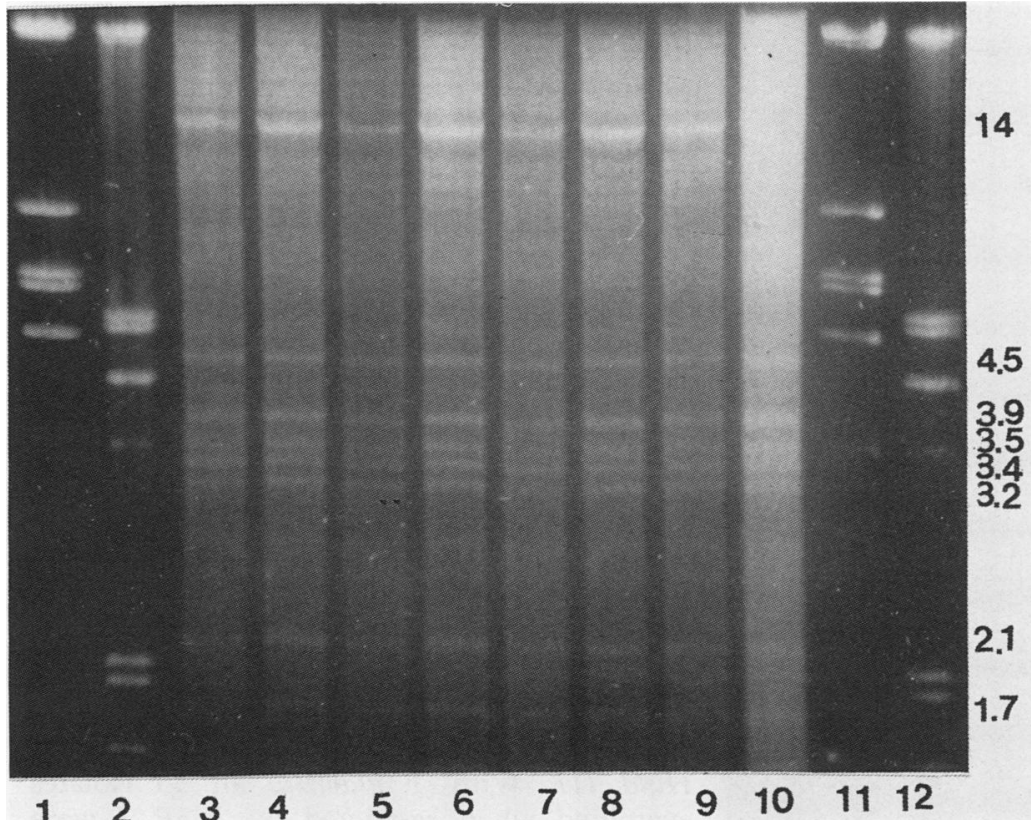

Figure 1 Tracks 1, 2, 11 and 12 molecular weight markers. Tracks 3-10 EcoR I digested $A$ fumigatus isolates.

mixing with equal volumes of 1-butanol saturated with distilled water. The aqueous phase was removed and the extraction repeated six times until the pink colour was removed from both phases. This was checked under ultraviolet light. The $\mathrm{CsCl}$ was removed by diluting the DNA with twice the volume of distilled water. The DNA was precipitated by two volumes of ice cold absolute ethanol at $-20^{\circ} \mathrm{C}$ overnight. It was centrifuged at 10000

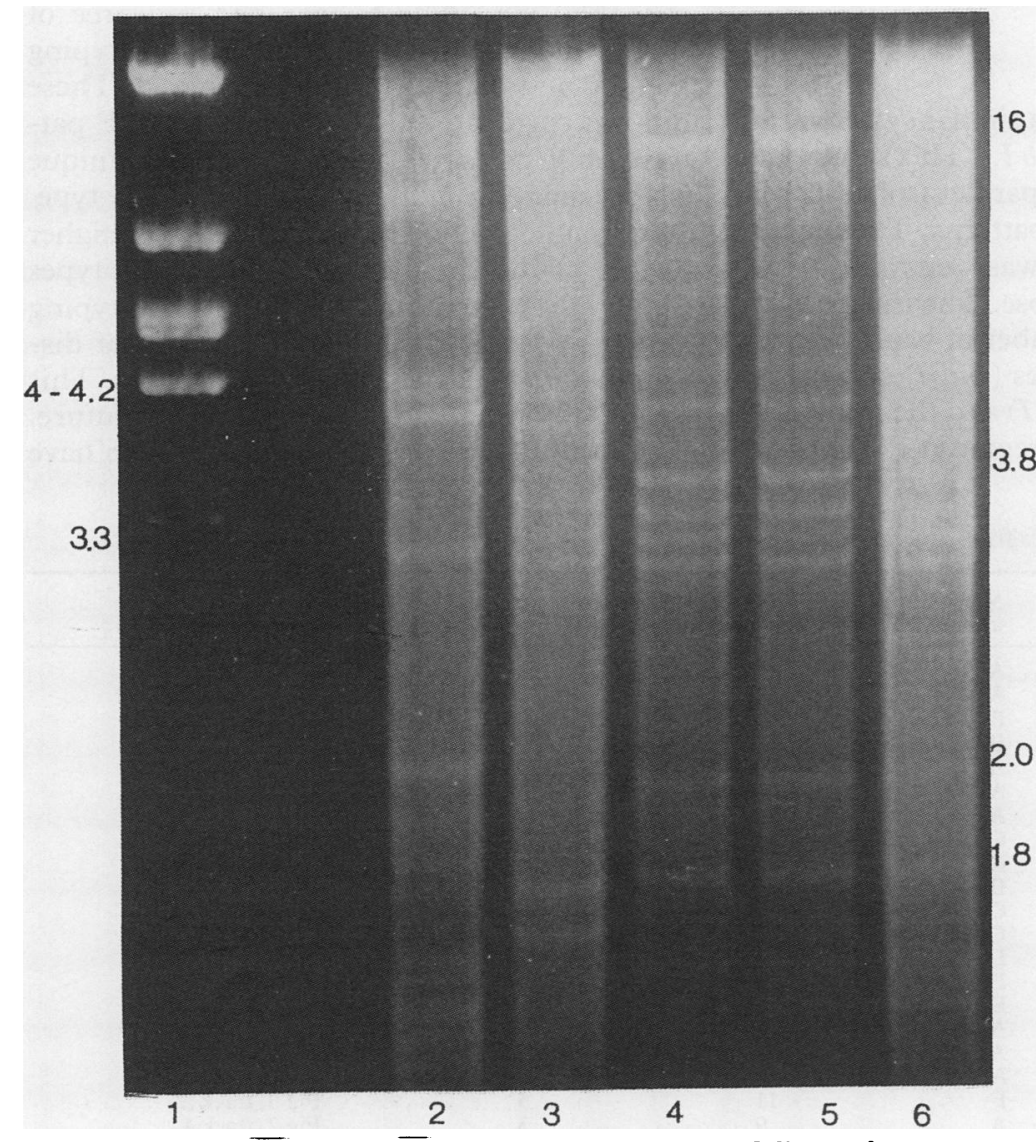

Figure 2 Track 1 molecular weight marker. Tracks 2-6 Xba I digests of A fumigatus isolates $2,18,20,21$ and 15 , respectively. rpm for 15 minutes at $4^{\circ} \mathrm{C}$. It was washed in $70 \%$ ethanol $(2 \times)$. The DNA was dried at $55^{\circ} \mathrm{C}$ for 10 minutes. Sterile distilled water $(360$ $\mu \mathrm{l})$ was added to dissolve the DNA at $55^{\circ} \mathrm{C}$ for 20 minutes. TE buffer $(40 \mu \mathrm{l}$ of $10 \times)$ was then added.

Reaction buffer $(10 \mu \mathrm{l})$ and $5 \mu \mathrm{l}$ of enzyme (NBL Enzymes Division, Cramlington) (EcoR $I$ or $X b a I)$ and $45 \mu$ ldistilled water were added to the DNA, giving a final volume of $100 \mu \mathrm{l}$. Endonuclease digestion was carried out to completion by incubating at $37^{\circ} \mathrm{C}$ for two hours. The digestion was stopped by heating the mixture to $70^{\circ} \mathrm{C}$ for 10 minutes.

Twenty per cent Ficoll $(5 \mu \mathrm{l})$ was added to the digested DNA sample and also to both the Hind $I I I$ digested $\lambda$ DNA and Hind $I I I / E c o R I$ digested $\lambda$ DNA $(150 \mathrm{mg} / \mathrm{ml})$ as size markers. Electrophoresis of these samples was carried out overnight at 40 volts (constant voltage) in a $300 \mathrm{ml}$ horizontal gel containing $0.8 \%$ agarose and $15 \mu \mathrm{l}$ of ethidium bromide $(10 \mathrm{mg} / \mathrm{ml})$. The gel was run in TRIS-borate-EDTA buffer. ${ }^{14}$ After electrophoresis the bands were visualised under ultraviolet light and photographed with a Polaroid type 57 film.

\section{Results}

Typing systems can be assessed by three criteria: typability, reproducibility, and discrimination. All isolates were typable with both enzymes and reproducibility was excellent between gels. Each isolate was examined at least three times. The enzyme $E c o R I$ produced no discrimination between isolates. Bright bands were detected at $14,4.5,3.9,3 \cdot 5,3 \cdot 4,3 \cdot 2,2 \cdot 1$ and 1.7 kilobases. Eight of the isolates are illustrated in fig 1 . These represent a single isolate from each case and the control isolate $A$ fumigatus NCPF 2109 in track 3.

$X b a I$ delineated six DNA types. It showed bright variable bands at $16,4-4 \cdot 2,3 \cdot 8,3 \cdot 3,2$ and 1 kilobases. The criteria for distinguishing between isolates are summarised in table 1 . DNA types 1,2 , and 3 are illustrated in fig 2 and DNA types 4,5 , and 6 in fig 3. The different DNA types described were correlated with the results previously obtained by immunoblot fingerprinting in table $2 .^{4} A$ fumigatus NCPF 2109 produced an identical DNA type to the isolate from case 1 . In cases 1 and 2 only a single isolate was available for examination. In cases 5 and 6 variation in immunoblot fingerprints did not correlate with differences in RFLP types. In cases 3, 4, and 7

Table 1 Details of six types of $A$ fumigatus generated by $D N A$ fingerprinting

\begin{tabular}{|c|c|c|c|c|c|c|}
\hline \multirow{2}{*}{$\begin{array}{l}\text { Band } \\
\text { (kilobases) }\end{array}$} & \multicolumn{6}{|c|}{ DNA types (Xba I digest) } \\
\hline & 1 & 2 & 3 & 4 & 5 & 6 \\
\hline $\begin{array}{l}16 \\
4-4 \cdot 2\end{array}$ & $\begin{array}{l}\overline{-}^{2} \\
\text { Triple } \\
\text { band }\end{array}$ & $\overline{t^{3}}$ & $\begin{array}{l}+ \\
+\end{array}$ & $\overline{+}$ & \pm & $\overline{+}$ \\
\hline $\begin{array}{l}3 \cdot 8 \\
3 \cdot 3\end{array}$ & + & $\begin{array}{l}\text { Double } \\
\text { band }\end{array}$ & $\begin{array}{l}+ \\
\text { Triple } \\
\text { band }\end{array}$ & $\begin{array}{l}+ \\
+\end{array}$ & $\bar{T}_{\text {race }}$ & $\bar{t}$ \\
\hline $\begin{array}{l}2.0 \\
1.8\end{array}$ & $\begin{array}{l}+1 \\
+1\end{array}$ & $\overline{+}$ & + & - & $\overline{-}$ & - \\
\hline
\end{tabular}




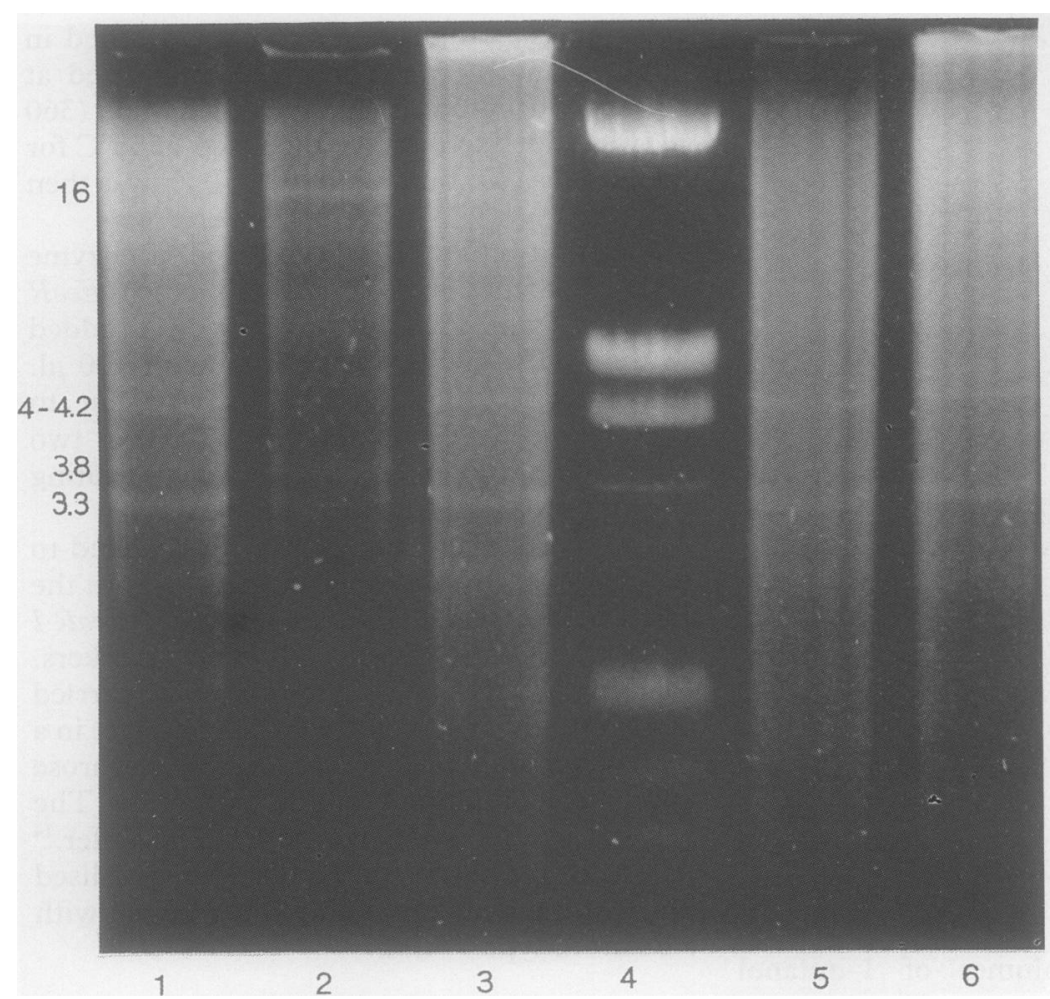

Figure 3 Track 4 molecular weight marker. Tracks 1-3, 5 and 6 Xba I digests of $A$ fumigatus isolates $1,19,8,11$ and 13 , respectively.

the multiple isolates from within the same aspergilloma produced identical immunoblot and RFLP types. In case 8 variation in immunoblot profile correlated with the presence of three separate RFLP types from within the lesion.

\section{Discussion}

Denning et al developed a similar system using the enzymes Sal $I$ and $X h o I .{ }^{15}$ This subdivided 31 epidemiologically separate isolates from three continents into 24 patterns. The method of DNA extraction was enzymic with novozyme 234 and cellulose. The isolates were differentiated by the number of bands above a heavy band at 23 kilobases ( $\mathrm{Sal} I$ ) or between 21 and 23 kilobases ( $X h o I$ ) and the number of bands down to a constant region at 12 kilobases.
These criteria differ from most typing systems involving restriction fragment length polymorphisms where isolates are distinguished by variation in the brighter DNA bands. The use of faint bands is questionable as these are the least likely to be reproducible. They were used because the yield of DNA following enzymic extraction was low. ${ }^{15}$ This problem was encountered by ourselves and overcome by the technique presented here involving the extraction of DNA from a freeze-dried extract. ${ }^{16}$

RFLP analysis has been used successfully to type both $C$ albicans ${ }^{56}$ and Candida tropicalis. ${ }^{9}$ In both cases variation in the position of bright DNA bands was used to delineate between strains and identify cross-infection. The application of the technique to Candida parapsilosis $^{8}$ and Torulopsis glabrata ${ }^{7}$ was less rewarding. With $C$ parapsilosis all isolates were identical when digested with the enzymes $E c o R$ I, Bam HI, Kpn I, Bgl II, Hpa II, Pvu II or Hind III. With $T$ glabrata all 33 isolates examined when restricted by $E c o R I$ were indistinguishable. $X b a I$ delineated five types of which one was responsible for an outbreak.

In the case of $A$ fumigatus all 21 isolates from the eight patients with an aspergilloma were identical when restricted with EcoR I. Xba I identified six types (table 2). Denning et al showed that patients harboured multiple isolates of $A$ fumigatus in their pulmonary secretions concurrently and over time. ${ }^{15}$ The results presented here show that aspergillomas may contain isolates of the same genotype (cases $3,4,5,6,7$ ) or different genotype (case 8). A fumigatus has been previously typed by both silver staining SDS-PAGE and immunoblotting. ${ }^{4}$ The former had a degree of discrimination similar to the RFLP typing method and defined six types (table 2). These did not correlate exactly with the RFLP patterns, but in case 8 , isolate 18 had a unique silver stain, immunoblot, and RFLP type. Immunoblot fingerprinting had a higher degree of discrimination producing 11 types (table 2). The combination of the three typing systems permitted an adequate degree of discrimination between $A$ fumigatus isolates. This will be applied epidemiologically in the future. The results show that the isolates, which have

Table 2 Details of RFLP types from aspergilloma isolates

\begin{tabular}{|c|c|c|c|c|c|}
\hline $\begin{array}{l}\text { No of } \\
\text { isolates }\end{array}$ & $\begin{array}{l}\text { Case } \\
\text { No }\end{array}$ & $\begin{array}{l}\text { Silver } \\
\text { stain type }\end{array}$ & $\begin{array}{l}\text { Immunoblot } \\
\text { type }\end{array}$ & $\begin{array}{l}\text { RFLP } \\
\text { type }\end{array}$ & Illustration \\
\hline $\begin{array}{r}1 \\
2 \\
3 \\
4 \\
5 \\
6 \\
7 \\
8 \\
9 \\
10 \\
11 \\
12 \\
13 \\
14 \\
15 \\
16 \\
17 \\
18 \\
19 \\
20 \\
21\end{array}$ & $\begin{array}{l}1 \\
2 \\
3 \\
3 \\
4 \\
4 \\
4 \\
5 \\
5 \\
5 \\
6 \\
6 \\
6 \\
7 \\
7 \\
8 \\
8 \\
8 \\
8 \\
8 \\
8\end{array}$ & $\begin{array}{l}\text { A } \\
\text { A } \\
\text { B } \\
\text { B } \\
\text { A } \\
\text { A } \\
\text { A } \\
\text { C } \\
\text { D } \\
\text { D } \\
\text { C } \\
\text { C } \\
\text { D } \\
\text { E } \\
\text { E } \\
\text { A } \\
\text { A } \\
\text { A } \\
\text { F } \\
\text { A } \\
\text { A }\end{array}$ & $\begin{array}{r}1 \\
2 \\
3 \\
3 \\
4 \\
4 \\
4 \\
5 \\
6 \\
6 \\
7 \\
7 \\
6 \\
8 \\
8 \\
9 \\
9 \\
10 \\
11 \\
9 \\
9\end{array}$ & $\begin{array}{l}4 \\
1\end{array}$ & $\begin{array}{l}\text { Fig 3, track } 3 \\
\text { Fig 3, track } 5 \\
\text { Fig 3, track } 6 \\
\text { Fig 2, track } 6 \\
\text { Fig 2, track } 3 \\
\text { Fig 3, track } 2 \\
\text { Fig 2, track } 4 \\
\text { Fig 2, track } 5\end{array}$ \\
\hline
\end{tabular}


been shown to be morphologically distinct ${ }^{13}$ from within an aspergilloma can be differentiated both in terms of pheno- and genotype.

RCM is a Wellcome Senior Research Fellow. The award was supported by a grant from The Trustees of the Manchester Medical School.

1 Opal SM, Asp AA, Cannady PB, Morse PL, Burton LD, Hammer PG. Efficacy of infection control measures Hammer PG. Efficacy of infection control measures during a nosocomial outbreak of disseminated asper1986;153:634-7.

2 Perraud M, Piens MA, Nicoloyannis N, Girard P, Sepetjan $M$, Garin JP. Invasive nosocomial pulmonary aspergillosis: risk factors and hospital building works. Epidemio Infect 1987;99:1147-50.

3 Dewhurst AG, Cooper MJ, Khan SM, Pallett AP, Dathan JRE. Invasive aspergillosis in immunosuppressed patients: potential hazard of hospital building work. $B M$ 1990;301:802-4.

4 Burnie JP, Matthews RC, Clark I. Milne LJR. Immunoblot fingerprinting Aspergillus fumigatus. J Immunol Methods 1989;118:179-86.

5 Matthews RC, Burnie JP. Assessment of DNA fingerprinting for rapid identification of outbreaks of systemic ing for rapid identification of

6 Scherer S, Stevens DA. Application of DNA typing methods to epidemiology and taxonomy of Candida species. J Clin Microbiol 1987;25:675-9.

7 Lee W, Burnie JP, Matthews RC, Oppenheim BO, Damani
NN. Hospital outbreaks with yeasts. J Hosp Infect 1991;18 (Supplement A) 237-49.

8 Carruba G, Pontieri E, de Bernardis F, Martino P, Cassone A. DNA fingerprinting and electophoretic karyotype of environmental and clinical isolates of Candida parapsilosis. J Clin Microbiol 1991;29:916-22.

9 Doebbeling BN, Hollis RJ, Isenberg HD, Wenzel RP Pfaller MA. Restriction fragment analysis of a Candida tropicalis outbreak of sternal wound infections. J Clin Microbiol 1991;29:1268-70.

10 Vincent RD, Goewert R, Goldman WE, Kobayashi GS, Lambowitz AM, Medoff G. Classification of Histoplasma capsulatum isolates by restriction fragment polymorphisms. J Bacteriol 1985;165:813-16.

11 de Bievre C, Dauguet C, Nguyen VH, Ibrahim-Granet $O$ Polymorphism in mitochrondrial DNA of several Polymorphism in mitochrondrial DNA of several Ann Inst Pasteur Microbiol 1987;138:719-27.

12 Wostemeyer J. Stain-dependent variation in ribosomal DNA arrangement in Absidia glauca. Eur $J$ Biochem 1985;146:443-8.

13 Leslie CE, Flannigan B, Milne LJR. Morphological studies on clinical isolates of Aspergillus fumigatus. $J \mathrm{Med} V e$ Mycol 1988;26:335-41.

14 Maniatis T, Fritsch EF, Sambrook J. Molecular cloning: a laboratory manual. Cold Spring Harbor, New York: Cold Spring Harbor Laboratory Press, 1978.

15 Denning DW, Clemons KV, Hanson LH, Stevens DA Restriction endonuclease analysis of total cellular DNA of Aspergillus fumigatus isolates of geographically and Aspergillus fumigatus isolates of geographically and
epidemiologically diverse origin. J Infect Dis 1990; 162:1151-8

16 Specht CA, DiRusso CC, Novotny CP, Ullrich RC. A method for extracting high-molecular-weight deoxyribonucleic acid from fungi. Analyt Biochem 1982 119:158-63. 